\title{
Environmental Impacts of Small Scale Irrigation Schemes: Evidence from Ethiopian Rift Valley Lake Basins
}

\author{
Mihret Dananto Ulsido ${ }^{1}$, Ermias Alemu Demisse ${ }^{2}$, Mekonen Ayana Gebul ${ }^{2}$ \\ and Adugna Eneyew Bekelle ${ }^{3}$ \\ ${ }^{1}$ School of Bio-systems and Environmental Engineering, Hawasa University, Ethiopia \\ ${ }^{2}$ Department of Water Resources and Irrigation Engineering, Arba Minch University, Ethiopia \\ ${ }^{3}$ Department of Agricultural Economics \& Extension, Jimma University, Ethiopia
}

cross $^{\text {ref }}$ http://dx.doi.org/10.5755/j01.erem.63.1.3401

(received in February, 2013, accepted in March, 2013)

\begin{abstract}
This research has been carried out in the Rift Valley Lakes Basin (RVLB), which is one of the twelve major river basins in Ethiopia. The RVLB has been considered in this research due to its high priority that comes from the significant ecological and environmental interest from different sectors. The research has tried to compare the relative environmental impact of Bedene Alemtena, Eballa, Argeda and Gedemso irrigation projects. Impact assessment at the community level has been collected on a base of key informant interviews and ad- hock technique. For the study, a summary of two sets of structured questioners are also used. Check lists, matrices, and rule based analysis are used to aggregate a scaled value of the individual parameters collected through the interviews and physical observations at the four sites. Deforestation, overgrazing, poor watershed management, soil salinity, soil acidity, communicable and non communicable diseases, and water logging are the major problems of all schemes. Specifically, about $34 \%$ of respondents have encountered soil fertility deterioration in Argeda, Gedemso and Bedene Alemtena irrigation projects with high significant variation $\left(\mathrm{X}^{2}, 97.7\right)$. Land degradation scenario after the implementation of the projects is also reported in Argeda (19.9\%), Gedemso (10.4\%), Ebala (23.8\%), Bedene Alemtena (33.3\%) ( $\mathrm{X}^{2}, 86.3$ ). About $76.2 \%$ of farmers in Argeda irrigation project have perceived that soil erosion in their plot is significantly more severe than other schemes $\left(X^{2}, 198.3\right)$. The comparison based on aggregated values shows that the Argeda 01 and Gedemso 01 irrigation projects have environmentally performed better than the Eballa and Bedene Alemtena irrigation projects.
\end{abstract}

Keywords: Check list, Matrices, Rule based analysis, Environmental Impact.

\section{Introduction}

The challenge of food insecurity in many developing countries is a concern and it is also a bottleneck problem in Ethiopia. The major cause of food insecurity in the country is due to its dependence on rain-fed agriculture and inability to develop the irrigation potentials. Ethiopia has about twelve river basins with a potential to irrigate an estimated area of 3.5 million ha, out of which only 190,000 ha $(4.3 \%)$ is actually under irrigation (Makombe et al. 2007; Tesfaye et al. 2008). It is indicated that escalation of irrigation development is crucial for reliable and sustainable food security in the country (Awulachew et al. 2007; Awulachew and Merrey 2007; Angood et al. 2002, 2003). The need for production and productivity improvement to alleviate the challenge of food insecurity obligates the use of irrigation, particularly in water deficit areas (Barrow 1993; MoWR 2001)

In Ethiopia, although irrigation has been long practiced at different farm levels, there is no efficient and well managed irrigation water practice (Dessalegn 1999), which directly or indirectly affects the environment. Environmental impact refers to any change in the environment or in its components that may affect human health or safety, flora, fauna, soil, air, water, climate, natural or cultural heritage, and 
other physical structures, social, economic or cultural conditions (EEPA 2003). The most important step in setting up the legal framework for the environment in Ethiopia has been the establishment of EEPA (Ethiopian Environmental Protection Authority) (EEPA 1995) by the proclamation No. 9/1995. EEPA is a front runner in the issues related to the environment in Ethiopians' day to day life. The issue of environmental impact assessment (EIA) gets momentum since 2002 after the parliament endorsed the EIA proclamation number 299/2002(FNG, 2002). Then, onwards, the issue of EIA is a prerequisite before the approval of most projects before their implementation.

Despite the positive contribution of irrigation development for food security and poverty reduction, many irrigation schemes have been unsuccessful and even have had negative impacts (De Fraiture et al. 2009). Irrigation planners need to consider evaluating whether the existing small scale irrigation (SSI) schemes are performing to the required level with substantial food security and environmental quality to make further irrigation development desirable and justified. Most studies on the SSI schemes focus on technical irrigation performance evaluation, but better availability of water by itself is not a sufficient condition, while several factors determine to maximize agricultural production, thereby improving household food security. Van Den Burg and Ruben (2006) also state that the studies focus on technical evaluation of irrigation schemes in Ethiopia, and only little is known about environmental issues, food security, and socioeconomic implications. Even though assessments of the contribution of SSI interventions to food security and livelihood diversification in Ethiopia are limited (IFAD 2005), some results have indicated that sometimes no difference is observed between rainfed and SSI user smallholders in their food security status (Peden et al. 2002). Developing an understanding of the potential environmental impact of SSI (Dougherty and Hall 1995) on the users helps to take appropriate measures in the ongoing irrigation development efforts of the country. Therefore, the general objective of this research is to understand the present and future environmental impacts of smallholder irrigation schemes on the Ethiopian Rift Valley lake basin through careful investigation of cases from the four irrigation schemes. The specific objectives are:

assessment and characterization of the schemes at their level of environmental aspects;

identification of environmental impact assessment indicators and design means to find out how to measure these indicators;

evaluation of the environmental situations of the four projects and extraction of the lessons for other schemes in the basin.

\section{Methods}

\subsection{Description of the study sites}

The Rift Valley Basin (RVB) has an area of $52,739 \mathrm{Km}^{2}$, covering parts of the Oromia, Southern Nations and Nationalities peoples (SNNPR) regions (Figure 1). The basin extends between the latitudes of $07^{\circ} 00^{\prime}$ and $08^{\circ} 30^{\prime} \mathrm{N}$ and between the longitudes of $38^{\circ} 00^{\prime}$ and $39^{\circ} 30^{\prime} \mathrm{E}$. The total mean annual flow from the River Basins is estimated at about 5.6 BMC (Awulachew et al. 2007). It has substantial areas of productive rain-fed agricultural land, good rangelands, and also irrigation lands due to the great demand for economic and social development. Irrigation development is growing in the basin, where about $10 \%$ of the estimated irrigation potential of 139,300 ha of irrigation land is under irrigation, out of which about 4627 ha is provided by small scale irrigation schemes. For this study, four sites, namely, Gedemso 01, Argeda, Bedene Alemtena and Eballa located within the basin have been selected; the former two of which are located in Oromiya and the other two are located in SNNP Administrative Regions. The reasons for the selection of these sites were: accessibility, scale, management type, agro ecological similarity, and market outlet.

Gedemso 01 SSI scheme constructed in 2001 by Oromiya Regional Government is located in West Arsi zone in Arsi Nagelle district, Buku Woldaya Kebele, 30 kilometers to the East of the district capital, Arsi Nagelle and 224 kilometers to the south East of Addis Ababa, Ethiopia. The scheme has a potential to irrigate 180 hectares (BoA 2009/10); out of which 80 hectares are located in Gedemso 01 (BoA 2009/10; Awulachew et al. 2007), and the remaining 100 hectares are located in Gedemso 02.

Argeda SSI scheme constructed by Oromiya regional government in 2004 is also located in West Arsi Zone in Arsi Nagelle district in Argeda Shaldo Kebele, 39 kilometers to the east of Arsi Nagelle and 233 kilometers to the Southeast of Addis Ababa, Ethiopia. The potential irrigable land of the scheme is 80 hectares (Awulachew et al. 2007).

Bedene Alemtena SSI project is located in SNNP administrative region in Halaba special Woreda. The project is located 12 kilometers from the Woreda capital, Halaba Kulito town. The scheme was constructed by CoSAERSAR to irrigate 200 ha (Awulachew et al. 2007).

Eballa SSI scheme is located in SNNP administrative region in Kembata Tembaro Zone in Hamido Goforo kebele. It is located at a distance of 120 kilometres to the Northwest of Hawassa, the regional capital. The scheme was constructed by CoSAERSAR in 1997 to irrigate an area of 120 hectares (Awulachew et al. 2007; Mihret 2006). The planned beneficiaries of the scheme are 627 households. Both schemes use similar diversion structures to guide the water into a gravity water distribution system. 
Those projects, listed in the guidelines prepared by EEPA that are likely to entail significant adverse environmental impacts, require EIA (EEPA 2003). They are broadly categorized under the sectors: agriculture (including irrigation), industry, transport, mining, dams and reservoirs, tannery, textile, hydropower generation, medium and big irrigation schemes, and resettlement projects. Currently, about 193 specific projects are identified under the "projects that need complete EIA" category. For these projects it is a compulsory to submit the Environmental Impact Study report prior to project implementation (EEPA 2003), while small scale irrigation schemes have waived from these requirements.

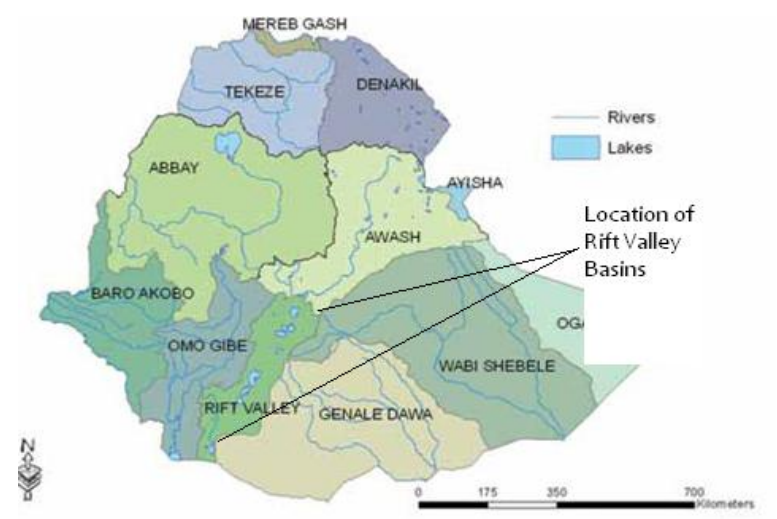

Fig. 1. Location of the study sites (Awulachew et al. 2007)

Indicators: The indicators presented in Table 1 are used to assess environmental performance of SSI projects. The indicators are selected according to the context of this research, i.e. major anticipated impacts and the cost of data collection and processing (Asit 1985). They are also based on the monitoring criteria of environmental impact assessment guidelines for medium and big irrigation schemes for the Federal Democratic Republic of Ethiopia (EEPA 2004).

\subsection{Environmental Impact Assessment Approach and Methods}

In view of the current situation of each project, this post project impact assessment research has employed a range of tools to gather and analyze data from both primary and secondary sources. The study approach basically follows the requirements stipulated in the irrigation EIA guidelines for the Federal Democratic Republic of Ethiopia (EEPA 2004). The data collection methods include the following:

\subsection{Document Review and Secondary data collection}

Relevant project documents have been reviewed during the preparation of field data collection tools and thoroughly reviewed during the preparation of the report. The reports include performance report, midterm review, baselines, beneficiary assessment, inventory, project completion report, etc.

Table 1. Indicators used for research

\begin{tabular}{||l|l||}
\hline $\begin{array}{l}\text { Human Interest } \\
\text { communication (Survey) }\end{array}$ & $\begin{array}{l}\text { Acquired irrigation systems management skills by trained men and women } \\
\text { (Survey and FGD). }\end{array}$ \\
\hline $\begin{array}{l}\text { Status of irrigation infrastructures } \\
\text { and services (Field } \\
\text { observation/transect walk and } \\
\text { measurement) }\end{array}$ & $\begin{array}{l}\text { Maintenance expenses on irrigation canals (FGD, KII). } \\
\text { Number of breakdowns of the irrigation systems.(KII, transect walk) }\end{array}$ \\
\hline Human health problems & $\begin{array}{l}\text { Household survey to study "before" and "after" irrigation scenario of } \\
\text { human health problems } \\
\text { Prevalence rates of diseases such as malaria, schistosomiasis, and } \\
\text { diarrhoea. (FGD, KII) } \\
\text { Number of vector breeding sites and vector density.( transect walk) } \\
\text { Availability of impregnated bednets, mosquito repellents. (FGD, KII) }\end{array}$ \\
\hline Water borne diseases & $\begin{array}{l}\text { Household survey to study "before" and "after" irrigation scenario of water } \\
\text { borne diseases. }\end{array}$ \\
\hline Malaria incidence after irrigation & $\begin{array}{l}\text { Household survey to study "before" and "after" irrigation scenario of } \\
\text { malaria incidences. } \\
\text { Prevalence rates of malaria(FGD, KII) }\end{array}$ \\
\hline Physico-Chemical Parameters & $\begin{array}{l}\text { Household survey to study "before" and "after" irrigation scenario of soil } \\
\text { fertility }\end{array}$ \\
\hline Soil Fertility & $\begin{array}{l}\text { Observation of the extent of erosion in Irrigation schemes } \\
\text { Household survey to study "before" and "after" irrigation scenario of soil } \\
\text { Sorosion }\end{array}$ \\
\hline \hline
\end{tabular}




\begin{tabular}{|c|c|}
\hline Sedimentation & Observation of the extent of sedimentation in Irrigation infrastructures \\
\hline Soil salinity & Changes in soil chemical parameters (ECe) \\
\hline Soil Acidity & Changes in soil chemical parameters $(\mathrm{pH})$. \\
\hline Land Degradation & $\begin{array}{l}\text { Household survey to study "before" and "after" irrigation scenario of land } \\
\text { degradation } \\
\text { Observation of the extent of land degradation in Irrigation schemes }\end{array}$ \\
\hline Land productivity & $\begin{array}{l}\text { Household survey to study "before" and "after" irrigation scenario of land } \\
\text { productivity } \\
\text { Observation of the extent of land degradation in Irrigation schemes }\end{array}$ \\
\hline Drainage and Water logging & $\begin{array}{l}\text { Observation of the extent of drainage problems and water logging in } \\
\text { Irrigation schemes }\end{array}$ \\
\hline Regional Hydrology/Flooding & Observation of back water effects Irrigation schemes headwork structures \\
\hline Obstruction of movement & Observation of movement obstructions for humans and livestock \\
\hline \multicolumn{2}{|l|}{ Ecology } \\
\hline Species diversity & $\begin{array}{l}\text { Inventory of wild animals and plant species before and after the project. } \\
\text { (FGD and KII). Base flow release during irrigation peak seasons (transect } \\
\text { walk) }\end{array}$ \\
\hline Aquatic weeds & Irrigation infrastructures visit (transect walk) \\
\hline Size of grazing land reduction & \multirow{2}{*}{$\begin{array}{l}\text { Household survey to study "before" and "after" irrigation scenario of forest } \\
\text { land }\end{array}$} \\
\hline Size of forest land reduction & \\
\hline Watershed Management Practice & Upstream catchments visit (transect walk) \\
\hline
\end{tabular}

\subsection{Focus Group Discussion}

Focus group discussions have been conducted with community representatives, Health extension workers, and DA's with special attention to the Environmental indicators listed above. In all irrigation schemes, the focus group discussions with organized groups are the main sources of information on the environmental performances of SSI projects.

\subsection{Key Informant Interview}

Key informant interview has been made with different professionals working in various government sector offices, regional level irrigation offices and community level workers, and with individuals, mainly with community representatives, women, elders, scheme representatives. A scaling checklist is used to capture the relative rating of each impact and to guide the evaluation of different criteria. The Battelle Environment Evaluation Index (EIV) is used to aggregate the data collected by scaled checklists.

$$
E I V=\sum_{i=1}^{n}\left(V_{i}\right) W_{i}
$$

where:

EIV - Battelle environmental index value;

$\mathrm{Vi}$ - relative change of the environmental quality of parameters;

$\mathrm{Wi}$ - relative importance or weight or parameter; $\mathrm{n}$ - $\quad$ total number of environmental parameters.

Relative changes of environmental parameters were given numerical values according to their impact extent as: Severe $(+5$ or -5$)$, Higher $(+4$ or -4$)$, Moderate $(+3$ or -3$)$, Low $(+2$ or -2$)$, Very Low $(+1$ or $-1)$ and No change (0).

Relative importance of Environmental Parameters (Wi) indicates the weight a given parameter has based on its importance. It was not equally considered in terms of its importance or weight. It varies from country to country. With the Ethiopian context, those parameters which contribute positively to the Growth and Transformation Plan (GTP) of the country, as food security, employment, agriculture, natural resource management are more important than the others and are scored higher weight in the analysis (see Table 7).

\subsection{Field Visit and Observation (transect walk)}

Field investigation and site observation with scheme's users by the research team have been an approach used under this technique. The team made field visits to each irrigation schemes plot-by-plot to visually observe the current environmental situations in the schemes. Observations into various schemes helped in knowing their status and identifying constraints in sustaining the services of the schemes to the targeted communities. On the spot, discussions with the scheme management committees and scheme users were conducted in a way to get first-hand information. The structured walk through the schemes 
helped assess particular indicators (water availability, maintenance status, soil type, soil characteristics, crops irrigated, land use, and watershed status).

\subsection{Household Survey}

Household survey in the four irrigation schemes was conducted using a structured questioner. Adverse impacts of irrigation schemes and harmful traditional practices that affected the community were identified. Farm households using directly the irrigation schemes were surveyed to see their environmental impacts. The study employed a 'before' and 'after' irrigation and 'with' and 'without' irrigation approach. A probability sampling method involving a simple random sampling technique was used to select the respondents. Proportional sampling was employed to pick female headed $\mathrm{HH}$ and male headed households from each strata. 147 irrigation scheme user households were involved in the study.

\subsection{Soil Sample Analysis}

Soil samples were taken for $\mathrm{pH}$, texture, electric conductivity of soil saturated extracts and bulk density analysis. Six sampling points (three from irrigated and three from rain fed farms) at the head (field 1), middle reach (field 2) and tail (field 3) were considered.

\section{Results and Discussion}

\subsection{Functionality of SSI schemes}

Although irrigated agriculture in the study areas has contributed to increased food production and to over- all socio-economic development, the schemes, observation and interviews made with the users have confirmed an increased environmental degradation. Even though the extent is different; off-farm and onfarm soil erosion, aquatic weeds infestation, sedimentation, infrastructural deterioration, unjust water distribution, and overgrazing are observed on the four irrigation schemes. Farmers' opinion and the field observation have proved that plowing of sloppy irrigated fields is the main cause of this problem. In Argeda 01 SSI scheme, the head work is filled with sediments to almost more than three quarters of the height of the weir. The two under sluice gates are functioning properly, but it is difficult to operate them because of rust and clogging.

Scheme conveyance structures' cracking and breaching, weed growth, sedimentation on the main canal and side scouring by livestock hooves, jumping and walking over the main canal are the problems frequently observed in Gedemso 01, Argeda, Bedene Alemtena and Eballa SSI schemes. In all schemes, there is no strategically constructed main canal crossing structure for safe passage of livestock. Weed growth and sedimentation are the major problems especially along the earthen canal in all schemes. Poor design of some drainage structures and lack of proper watershed management consideration at the upper catchment above the diversion weir during the scheme study \& design have been the causes of the problems.

In Gedemso 01, Bedene Alemtena and Eballa SSI, the off-takes have no water controlling mechanisms, no gates installed, and farmers are using locally available materials to manage the gates. Division boxes are full of silts and rubbish. Generally, the main canal and the accompanying irrigation infrastructures lack continuous follow-up and frequent maintenance. Aquatic and terrestrial weeds, water theft, drainage problems, seepage, flow obstruction, and plowing of sloppy lands without proper conservation techniques are additional environmental problems observed in all schemes.

Due to upstream excessive abstraction, the farmers in the Argeda 01 SSI scheme are facing water shortage, particularly during the driest season (March). Downstream users are complaining about their water use right. Unless appropriate water sharing mechanism is implemented, this could be a possible cause for conflict in the near future. Though farmers have got technical training on irrigated field preparation in all schemes, there are still problems of improper furrow layout (length, spacing, and direction). Furrows are laid in some fields along the slope which aggravate erosion and non-uniform distribution of water among the plots. In recent times, farmers are complaining about the reduction in productivity of their farms because of fertile top soil erosion.

\subsection{Environmental impacts of SSI schemes}

Soil Fertility. The sample households have different opinions regarding fertility of their plots after irrigation. Overall, $66 \%, 30 \%$ and $4 \%$ of respondents, respectively, reported that their soil fertility level is high, medium and low. With respect to the irrigation schemes i.e. $36 \%, 57 \%$ and $7 \%$ of the respondents in Argeda-01; 29\%, 63\% and 8\% of the respondents in Gedemso 01; 93\%, 7\% and nil respondents in Eballa, and 90\%, $7 \%$ and $3 \%$ in Bedene Alemtena have stated that it is good, medium, and low after the implementation of the irrigation schemes, respectively (Table 2). The overall figure indicates that about $34 \%$ of the respondents have reported that their soil fertility status was deteriorated after irrigation. Unlike the others, Eballa irrigation scheme users are settlers coming from the neighboring village. That could be the reason, why 93\% of the respondents argued the betterment in fertility after the use of irrigation. The use of manure and chemical fertilizers after irrigation were mentioned during the FGD as a reason for increased soil fertility, while the continuous cultivation, intensification of agricultural production through irrigation, removal of nutrients more rapidly than their replenishment either through leaching or crop residue removed from the field for livestock feed, fuel, and 
house construction are mentioned as a reason for decreasing soil fertility.

Table 1. Soil fertility status after irrigation scheme constructed (\%)

\begin{tabular}{||c|c|c|c|c||}
\hline & Low & Medium & Good & $X^{2}$ \\
\hline Argeda 01 & 7 & 57 & 36 & \\
\cline { 1 - 4 } Gedemso 01 & 8 & 63 & 29 & \\
\cline { 1 - 4 } Ebala & 0 & 7 & $93.7 * * *$ \\
\cline { 1 - 4 } Bedene & 3 & 7 & 90 & \\
\cline { 1 - 4 } Total & 4 & 30 & 66 & \\
\hline
\end{tabular}

*** Significant at $(P<0.01), X^{2}-$ chi-square

Soil erosion. Most of the households perceived soil erosion as a major environmental treat to irrigated crop production. Even though the extent is different, $87.8 \%$ of the total households (Table 3 ) faced medium to high level of soil erosion on their plots, and this variation is statistically significant. Two major types of soil erosion were identified in this case study. Sheet erosion due to overtopping irrigation water and rill erosion was created due to the upstream seepage flowing out surface on downstream fields. Erosion due to wrongly aligned furrows was observed in Argeda 01 and Gedemso 01 irrigation schemes.
Table 2. Soil erosion exposure

\begin{tabular}{|c|c|c|c|c|}
\hline & Low & Medium & High & $X^{2}$ \\
\hline Argeda 01 & 2.6 & 21.1 & 76.2 & \multirow{5}{*}{$198.3^{* * *}$} \\
\hline Gedemso 01 & 33.0 & 55.4 & 10.7 & \\
\hline Ebala & 0.0 & 90.4 & 9.6 & \\
\hline Bedene & 12.1 & 80.3 & 7.6 & \\
\hline Total & 11.9 & 61.8 & 26 & \\
\hline
\end{tabular}

*** Significant at $(P<0.01), X^{2}-$ chi-square

Sedimentation. There is an evidence for the loss of irrigation structures functionality due to sedimentation (Abebe et al. 2003). Soil erosion and subsequent transport of sediments (and adsorbed chemicals) are caused by runoff of excess irrigation water from cropland. Sediments transported by irrigation tail waters eventually return to streams and rivers, negatively impacting canals and other water conveyance structures, causing sedimentation of irrigation structures, affecting the durability of irrigation structures, and creating significant problems to aquatic ecosystems. $85 \%$ of the respondents from the household survey believed that the problems of sedimentation in irrigated fields are increased year to year after the implementation of the irrigation schemes (Figure 2).

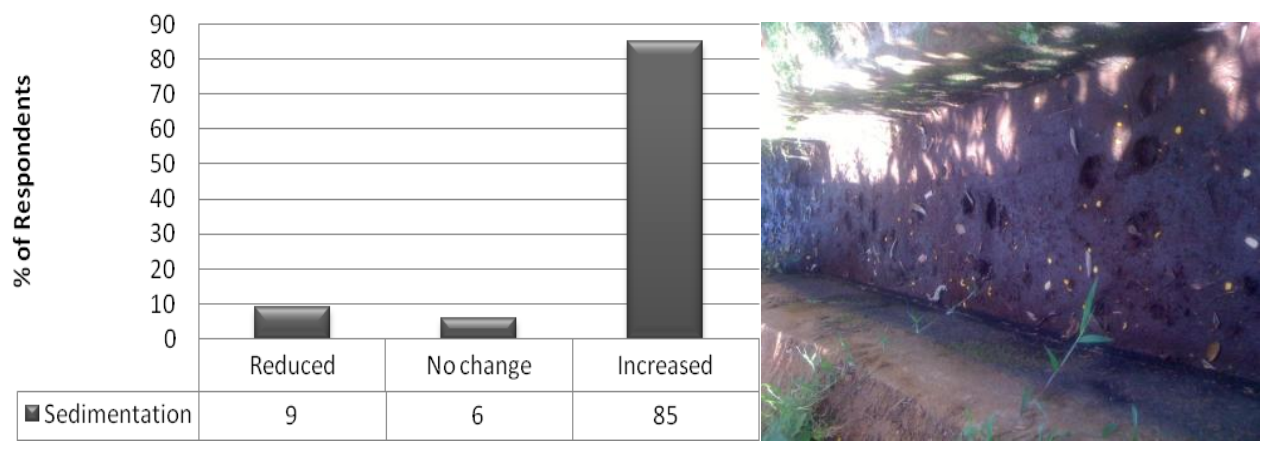

Fig. 2. Perception of farmers about sedimentation problems

Table 3. $\quad$ Electric conductivity (ECe) in irrigation schemes

\begin{tabular}{|c|c|c|c|c|c|c|c|c|c|}
\hline \multirow{3}{*}{$\begin{array}{c}\text { Field } \\
\text { location }\end{array}$} & \multirow{3}{*}{$\begin{array}{c}\text { Soil } \\
\text { Depth } \\
(\mathrm{cm})\end{array}$} & \multicolumn{8}{|c|}{$\mathrm{ECe}\left(\mathrm{dS} \mathrm{m} \mathrm{m}^{-1}\right)$} \\
\hline & & \multicolumn{2}{|c|}{ Eballa } & \multicolumn{2}{|c|}{ Bedene Alemtena } & \multicolumn{2}{|c|}{ Argeda 01} & \multicolumn{2}{|c|}{ Gedemso 01} \\
\hline & & IF & $\mathrm{RF}$ & $\mathrm{IF}$ & $\mathrm{RF}$ & IF & $\mathrm{RF}$ & IF & $\mathrm{RF}$ \\
\hline \multirow[b]{3}{*}{ Head } & $0-30$ & 0.415 & 0.252 & 0.397 & 0.135 & 0.065 & 0.063 & 0.191 & 0.129 \\
\hline & $30-60$ & 0.314 & 0.155 & 0.346 & 0.089 & 0.059 & 0.118 & 0.066 & 0.096 \\
\hline & $60-90$ & 0.221 & 0.16 & 0.231 & 0.189 & 0.05 & 0.08 & 0.065 & 0.139 \\
\hline \multirow[b]{3}{*}{ Middle reach } & $0-30$ & 0.414 & 0.28 & 0.426 & 0.099 & 0.235 & 0.108 & 0.091 & 0.058 \\
\hline & $30-60$ & 0.322 & 0.173 & 0.321 & 0.094 & 0.132 & 0.068 & 0.101 & 0.094 \\
\hline & $60-90$ & 0.232 & 0.152 & 0.237 & 0.116 & 0.087 & 0.082 & 0.011 & 0.134 \\
\hline \multirow[b]{3}{*}{ Tail } & $0-30$ & 0.499 & 0.423 & 0.433 & 0.149 & 0.111 & 0.059 & 0.259 & 0.066 \\
\hline & $30-60$ & 0.557 & 0.312 & 0.302 & 0.14 & 0.071 & 0.052 & 0.304 & 0.132 \\
\hline & $60-90$ & 0.557 & 0.234 & 0.209 & 0.255 & 0.075 & 0.08 & 0.274 & 0.25 \\
\hline
\end{tabular}

IF - Irrigated fieldsRF - Rainfed fields, EC - Electric Conductivity of soil saturated extract in deciSiemens per metre $\left(d S m^{-}\right.$ ${ }^{\text {l) }}$ at $25^{\circ} \mathrm{C}$ 
Deforestation, overgrazing, and intensive cultivation of the watershed upstream of irrigation headwork expose the watershed to erosion and high surface runoff. Population pressure aggravates this problem even more. The eroded material from the steep escarpments which is deposited on the irrigated canals and other infrastructures can lead to soil sedimentation.

Table 4.

Soil pH in irrigation schemes
Soil salinity. As compared to rain-fed fields, the elevated salinity levels have been measured in the studied irrigation schemes. As the soil gets deeper (Table 4), both Irrigated and Rain-fed fields show a nearly similar electric conductivity. This indicates that the source of salinity is not a natural weathering process but from irrigation water. Most irrigation waters contain some salts.

\begin{tabular}{|c|c|c|c|c|c|c|c|c|c|}
\hline \multirow[b]{3}{*}{ Field location } & \multirow{3}{*}{$\begin{array}{c}\text { Soil } \\
\text { depth }(\mathrm{cm})\end{array}$} & \multicolumn{8}{|c|}{ Soil saturated extract $\mathrm{pH}$ value } \\
\hline & & \multicolumn{2}{|c|}{ Argeda 01} & \multicolumn{2}{|c|}{ Bedene Alemtena } & \multicolumn{2}{|c|}{ Eballa } & \multicolumn{2}{|c|}{ Gedemso 01} \\
\hline & & IF & $\mathrm{RF}$ & IF & $\mathrm{RF}$ & IF & RF & IF & $\mathrm{RF}$ \\
\hline \multirow[b]{3}{*}{ Head } & $0-30$ & 6.92 & 6.57 & 7.05 & 7.81 & 7.3 & 7.99 & 6.8 & 6.82 \\
\hline & $30-60$ & 6.76 & 6.52 & 6.97 & 7.62 & 7.13 & 7.83 & 6.68 & 7.21 \\
\hline & $60-90$ & 6.6 & 5.93 & 7.41 & 7.37 & 6.57 & 7.7 & 6.56 & 7.45 \\
\hline \multirow[b]{3}{*}{ Middle reach } & $0-30$ & 6.24 & 6.75 & 6.74 & 7.56 & 7.55 & 7.87 & 7.7 & 6.13 \\
\hline & $30-60$ & 6.4 & 7.17 & 6.84 & 7.34 & 7.6 & 7.64 & 7.3 & 5.78 \\
\hline & $60-90$ & 6.38 & 7.55 & 7.23 & 6.98 & 7.8 & 7.35 & 6.98 & 5.83 \\
\hline \multirow[b]{3}{*}{ Tail } & $0-30$ & 7.18 & 6.76 & 6.86 & 7.99 & 7.5 & 7.56 & 7.84 & 7.65 \\
\hline & $30-60$ & 6.84 & 6.56 & 6.5 & 7.83 & 6.63 & 7.34 & 7.73 & 7.32 \\
\hline & $60-90$ & 6.32 & 6.34 & 8.1 & 7.7 & 6.63 & 6.98 & 7.53 & 7.36 \\
\hline
\end{tabular}

IF - Irrigated fields RF - Rainfed fields

Main causes of the development of salts are the use of saline irrigation water, seepage from the canals, and poor drainage as observed during the transect walk. As compared to the fields located at the head, tail fields suffer more to a salinity problem due to salt accumulation, because of the lack of a proper drainage system.
Soil Acidity. Compared to rain-fed fields, most of the irrigated fields exhibited lower $\mathrm{pH}$ values. Higher soil acidity is particularly observed at Eballa irrigation scheme (Table 5). Application of intensive commercial fertilizers and use of pesticides for tobacco cultivation are the main reason in this scheme. A similar trend is observed in Bedene Alemtena and Gedemso 01 irrigation projects, too.

Table 5. Level of land degradation

\begin{tabular}{|c|c|c|c|c|}
\hline & low & medium & High & \\
\hline Argeda 01 & 55.6 & 24.5 & 19.9 & $X^{2}$ \\
\hline Gedemso 01 & 45 & 45 & 10 & \multirow{4}{*}{$86.3 * * *$} \\
\hline Ebala & 0 & 76.3 & 23.7 & \\
\hline Bedene & 11.7 & 55 & 33.3 & \\
\hline Total & 28.1 & 50.2 & 21.7 & \\
\hline
\end{tabular}

*** Significant at $(P<0.01), X^{2}-$ chi-square

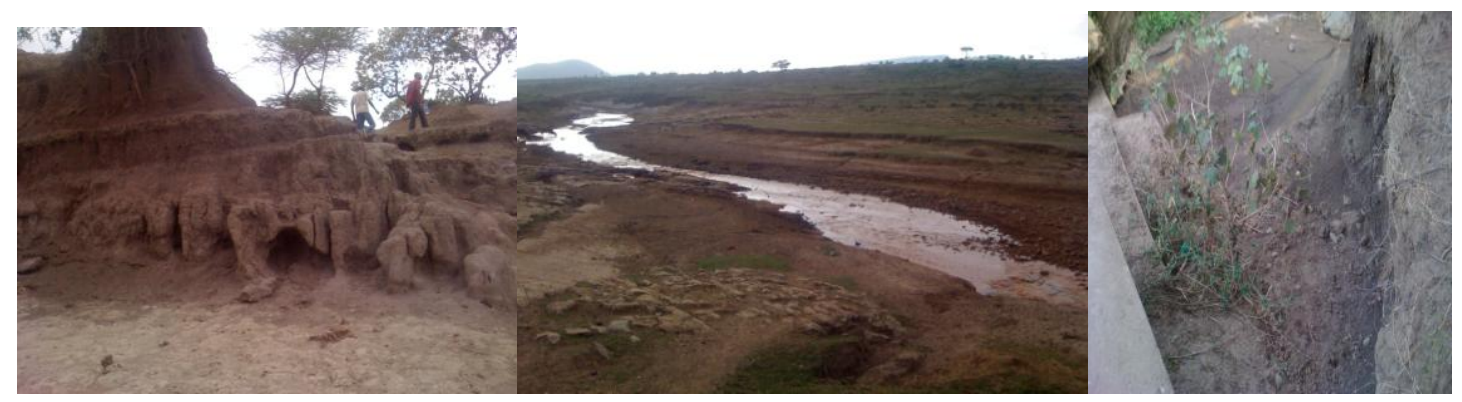

Fig. 3.

Evidence of land degradation and soil erosion

Land Degradation. More than $70 \%$ of respondents believe that land degradation is observed in their plots since the implementation of irrigation schemes (Table 6). Soil quality deterioration, erosion hazard, continuous cultivation, intensification of agricultural production through irrigation, removal of nutrients more rapidly than their replenishment either through leaching; or crop residue, removing from the 
field for livestock feed, fuel, and house construction are mentioned as the reason of land degradation (Figure 3). Crop and land suitability study has to be made for alternative crop rotation in Gedemso 01 and Argeda 01 irrigation schemes. Prolonged land cooling due to poor land drainage during the rainy season is observed in Bedene Alemtena irrigation project as a main cause for land degradation. Use of broad bed maker (BBM) is suggested to drain water ponding areas in irrigated fields. Similarly, in Eballa irrigation project, rotation of tobacco with millet is not an advisable strategy. Better nitrogen fixing crops should have to be used. Cover crop, crop residue management, and control grazing are good options to minimize the risk of soil erosion in the watershed.

Land productivity. Water is a limiting factor in crop production. Provision of water through irrigation is believed to improve land productivity. However, about $60 \%$ of respondents in the four irrigation projects think that there is no change in productivity after irrigation (Figure 4). Even in Gedemso 01 irrigation project, a significant proportion of respondents have mentioned a reduction in land productivity after irrigation.

About $5 \%$ of the total irrigable land in Gedemso 01, 3\% in Argeda 01 and 5\% in Bedene Alemttena irrigation projects suffer from water logging. As a result, productivity may have fallen significantly in these areas. Lack of a proper drainage system affects large areas of land in the four irrigation projects; in many cases these problems are compounded by salinization. As compared to the fields located at the head, tail fields suffer more to salinity problems due to drainage and reduction in land productivity. The respondents also substantiated the reduction in land productivity due to poor water management, increased intensity of birds and wild animals attack, erosion, and low soil temperature.
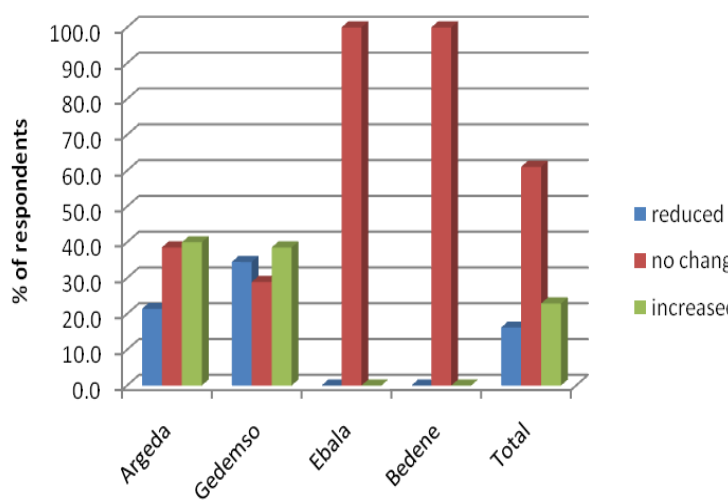

no change ๓increased

Fig. 4. Land productivity after irrigation

\section{Ecology.}

Size of grazing and forest land. About 91 and $85 \%$ of the total respondents indicated that there is a reduction in the size of grazing land (Figure 3) and forest coverage (Figure 5) in all irrigation schemes, respectively. Loss of species diversity (flora and fauna) was reported in all schemes. The current irrigation command area in Eballa irrigation project was used for communal grazing land. In Bedene Alemtena irrigation project the current command area was under rain fed crop production and used mainly for grazing land in the past. A similar trend was observed in Argeda 01 and Gedemso 01 projects, too. After the project was implemented, all newcomers, other than the original scheme users, took and changed the existing grazing land to irrigated land. Demographic change and livestock increment are also another reason for the reduction in grazing land in the four irrigation schemes.

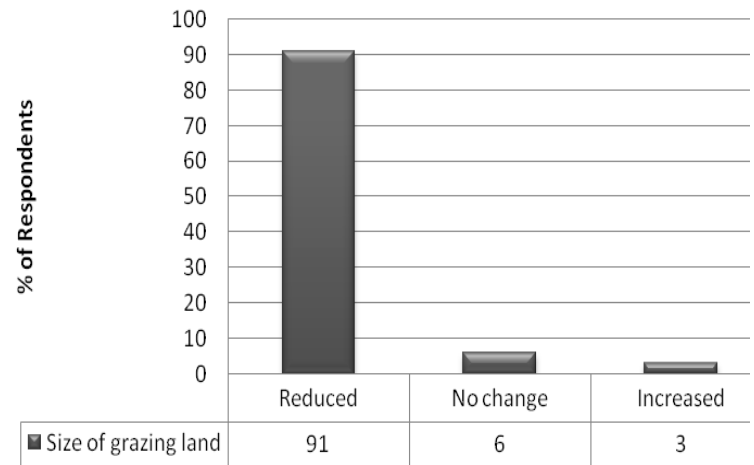

Fig. 5. Perception of farmers about grazing land status

A similar justification was made for the reduction in forests in the four irrigation projects (Figure 6). According to the FGD, dried out trees were freely used in the four projects to fulfill their needs of firewood. On the other hand, no strong attempt was reported on replacement of the dried ones and mitigation of cutting the existing trees and shrubs. Thus, in the future, due to the increase in population pressure \& need for farm land, maximum deforestation is expected, unless solution is devised to conserve available forest.

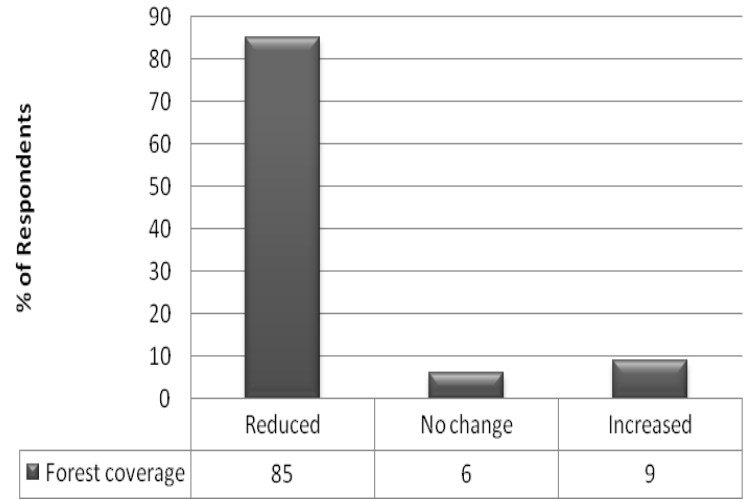

Fig. 6. Perception of farmers about forest coverage

Watershed Management Practice. Sedimentation problem usually arises from human disturbance of the prehistoric geologic pattern. Cutting and burning of bushes, shrubs, trees and forestlands lead to reduced vegetation cover and aggravates the process of erosion. Thus, an increased erosion problem causes transported sediments from 
unmanaged watersheds directly affecting the irrigation structures.

In all irrigation schemes studied, even $78 \%$ (Figure 7) of respondents believe that an increased watershed management practices after irrigation schemes, physical observation on irrigation schemes show irrigation infrastructure deterioration due to sedimentation problems. Even, if field sediment test is not done, the entire weirs in the four irrigation projects are heavily loaded with sediments. Engineering interventions that protect head work structures from sediment load are suggested for Bedene Alemtena, Gedemso 01 and Eballa irrigation projects.

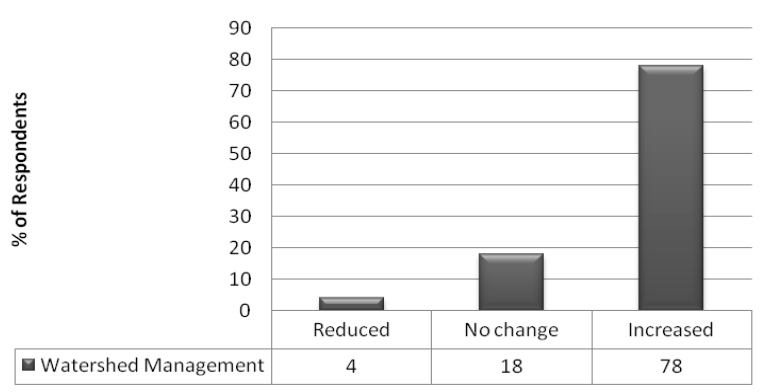

Fig.7. Perception of farmers about watershed management

Human Interest. Irrigation canals and the accompanying infrastructures are a source of water mainly for the growth of crops. But it also serves different purposes such as recreation, washing, and drinking for livestock and humans. However, the canals in the study area created swamp in different reaches. With the formation of the swamps, different pests and insects, majorly mosquitoes, have been introduced in most schemes. Due to this, malaria has become a major problem of the area that adds expenses of medication and reducing labor force for irrigation schemes.

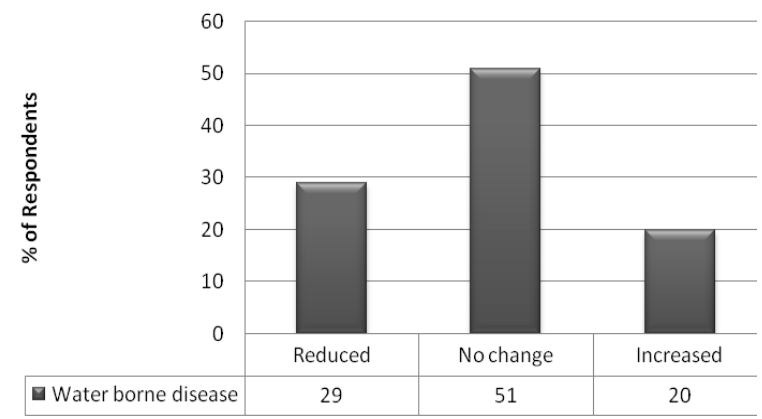

Fig. 8. Perception of farmers about water borne disease status

Human health problems. Polluted water is a major cause of human disease. About $20 \%$ of respondents (Figure 8) have reported the increased incidence of water borne diseases with the introduction of irrigation. About $30 \%$ of Argeda 01 and $33 \%$ of Gedemso 01 irrigation scheme users agree on the increment of water caused disease after the implementation of the irrigation projects; whereas 95\% of irrigation scheme users, each from Eballa and Bedene Alemtena irrigation projects, do not agree with the change in water borne disease scenario after irrigation.

Major reasons could be that the users in both Eballa and Bedene Alemtena irrigation projects have alternative places to live on, different from the irrigated fields. The other reason could be that farmers in Eballa and Bedene Alemtena irrigation projects cultivate tobacco and pepper, both of which are commercial crops not consumed raw at a household level, showing a low score of water borne diseases due to water contamination.

Malaria incidence after irrigation. About $63 \%$ of respondents from all irrigation projects have confirmed the increase in malaria incidences after the implementations of irrigation projects (Figure 9).

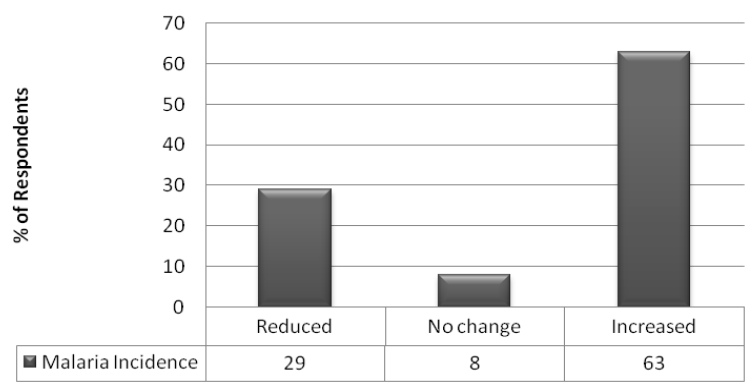

Fig. 9. Perception of farmers about malaria incidence

The survey has proved that most of child and adult deaths in the four irrigation schemes are caused by malaria. Malaria does have also forced the irrigators to spend their time and money for treatment and diminished effective labor availability at the household for production. Unlined canals in all irrigation projects posed other health problem for both humans and livestock. Water seeping from irrigation canals joining dwelling mud houses has created unwanted humidity of living homes, thus developing a fertile ground for fungal, viral and bacterial diseases and infestations.

Aggregation of Environmental Impacts. Overall environmental impacts of the four irrigation projects are aggregated using the Battelle Environment Evaluation Index (EIV). The results show that Argeda 01 and Gedemso 01 irrigation projects have environmentally performed better than Eballa and Bedene Alemtena irrigation projects (Table 7). Better organization of the schemes may attribute to the result. However, there exist a number of environmental issues, which need an immediate attention in all the analyzed projects. All the negative figures in Table 7 in front of each parameter need immediate attention to reverse the impact. 


\begin{tabular}{|c|c|c|c|c|c|c|c|c|c|}
\hline & Wi & \multicolumn{4}{|c|}{$\mathbf{V}_{\mathbf{i}}$} & \multicolumn{4}{|c|}{$\left(\mathbf{W}_{\mathrm{i}}\right)\left(\mathbf{V}_{\mathrm{i}}\right)$} \\
\hline & & Eba & Gedems & Arged & Bede & Eba & Gedems & Arge & Beden \\
\hline \multicolumn{10}{|l|}{ Physico-chemical } \\
\hline Soil Fertility & 3 & 0 & -3 & -2 & -1 & 0 & -9 & -6 & -3 \\
\hline Soil erosion & 3 & -2 & -3 & -5 & -1 & -6 & -9 & -15 & -3 \\
\hline Sedimentation & 4 & -3 & -2 & -1 & -4 & -12 & -8 & -4 & -16 \\
\hline Soil salinity & 4 & -4 & -3 & -1 & -5 & -16 & -12 & -4 & -20 \\
\hline Soil Acidity & 4 & -3 & -4 & -1 & -5 & -12 & -16 & -4 & -20 \\
\hline Land Degradation & 3 & -3 & -1 & -2 & -4 & -9 & -3 & -6 & -12 \\
\hline Drainage and Water logging & 3 & 0 & -2 & 0 & -4 & 0 & -6 & 0 & -12 \\
\hline Regional & 3 & 1 & 1 & 5 & 5 & 3 & 3 & 15 & 15 \\
\hline Obstruction of movement & 3 & -4 & -3 & -3 & -4 & -12 & -9 & -9 & -12 \\
\hline \multicolumn{10}{|l|}{ Ecology } \\
\hline Species diversity & 6 & -1 & -1 & 1 & 1 & -6 & -6 & 6 & 6 \\
\hline Aquatic weeds & 8 & -3 & -3 & -3 & -3 & -24 & -24 & -24 & -24 \\
\hline Grazing land reduction & 6 & -3 & -3 & -3 & -3 & -18 & -18 & -18 & -18 \\
\hline Forest land reduction & 6 & -3 & -3 & -3 & -3 & -18 & -18 & -18 & -18 \\
\hline Watershed Management & 7 & -5 & -2 & -2 & -5 & -35 & -14 & -14 & -35 \\
\hline \multicolumn{10}{|l|}{ Human Interest } \\
\hline Human health & 6 & 0 & -3 & -2 & 0 & 0 & -18 & -12 & 0 \\
\hline Water borne diseases & 4 & -3 & 0 & 0 & -3 & -12 & 0 & 0 & -12 \\
\hline Malaria incidence & 5 & -3 & -3 & -3 & -4 & -15 & -15 & -15 & -20 \\
\hline \multicolumn{6}{|c|}{ s ( Environmental impacts only) (EIV) } & & -191 & -134 & -204 \\
\hline
\end{tabular}

$V_{i}$ - relative change of the environmental quality (degree of Impact), $W_{i}$ - relative importance or weight, EIV-Environmental Index Value

\section{Conclusions}

In general, irrigation reduces the risk of expensive inputs being not wasted by crop failure resulting from moisture stress (FAO 1997). The report towards environmental impact assessment of a small scale irrigation project is mainly meant to minimize human and environmental hazards, thus strengthening better living standards without destroying the ecological balance of nature.

In all the projects studied, the problems of deforestation, overgrazing, poor watershed management, soil salinity, soil acidity, communicative and uncommunicative diseases and water logging are significant. In fact, the command, main canal, weir site, and access roads in each project are on the undulating plane, which was covered with wood land, forest, bushes \& riverine tress before. All this landscape phenomena were either sparsely existent or completely removed. For subduing these problems, compensation of environmentally friendly tree planting like Cordia africana is of great importance.

In addition to crop production, livestock production in its traditional form of husbandry supports the livelihood of the community in the four irrigation projects. Irrigated forage production is suggested to minimize the risk of overgrazing and compensating the forage from the lost grazing land.
Other impacts such as an effect on wild life and species diversity need better consideration in Eballa and Gedemso 01 irrigation projects.

A due emphasis should have to be given to proper soil and water conservation practices on the degraded upstream catchment of Bedene Alemtena and Eballa irrigation projects. The existing weak farming system needs to be developed and supported by technological inputs, thus the schemes will enhance return and will contribute to and answer the prevailing food self-sufficiency at a micro level with improved environmental quality.

The following irrigation scheme impacts related to the project operation and management, prior to their becoming worse, need an immediate attention:

1. Water logging due to inefficient use of water in Bedene Alemetena irrigation project.

2. Ecological and demographic changes created due to the projects favor the formation of conductive habitats for disease vectors, e.g. malaria. Coordinated field ditches drainage (maintenance) is recommended in tail water location of Bedene Alemetena irrigation project. Night storage pond in Gedemso 01 irrigation project is another location for mosquito breeding. Frequent weeding of aquatic plants is recommended.

3. Pesticide residues are the main cause for lowering the soil $\mathrm{pH}$ in Eballa irrigation project. 
Integrated pest management (IPM) instead of complete dependency on commercial pesticides is recommended. If the present application continues, it may cause risks not only to irrigated fields, but also to health of both man \& animals.

4. Irrigated agriculture provides improved conditions for aquatic weeds in all projects. Diseases and weeds also propagate quickly via the use of drainage water. Proper drainage water reuse and mechanical weed control strategy is recommended in all projects.

\section{Acknowledgements}

The authors would like to thank UNESCO-IHE (the University Water Sector Partnership- Demand Driven Action Research project) for financing this research, and Arba Minch and Hawasa Universities for providing the necessary facilities like office and vehicles. Our special thanks will be for Oromiya Water Mines and Energy bureau, Southern Nations Nationalities and Peoples Regional States Irrigation Development and Scheme Administration Agency. We are also highly indebted to Dr. Flip Wester, Dr. Frank van Steenbergen, Mrs. Susan Graas, Mr. Yohannis Geleta, Mr. Tadele M, Mr. Roba and Gezahegn Wejebo for their all round support to realize this research.

\section{References}

ABEBE, Y. D. and GEHEB, K. (Eds), 2003.Wetlands of Ethiopia. Proceedings of a seminar on the resources and status of Ethiopia's wetlands, VI + 116pp.

ANGOOD, C., CHANCELLOR, F., HASNIP, N., MORRISON, J., SMITH, L. 2002. Contribution of irrigation to sustaining rural livelihoods: Nepal case study. HR Wallingford technical report OD/TN 113, Wallingford, UK.

ANGOOD, C., CHANCELLOR, F., MORRISON, J., SMITH, L. 2003. Contribution of irrigation to sustaining rural livelihoods: Bangladesh case study. HR Wallingford technical report OD/TN 114, Wallingford, UK.

ASIT,K.B.1985. Evaluating irrigation's impact: guide lines for project monitoring, Ceres, Vol 18, NO 4,PP 26-32.

AWULACHEW S. B., MERREY D. J., KAMARA A. B., VAN KOPPEN B., F. PENNING DE VRIES AND BOELEE E.2005. Experiences and Opportunities for promoting Small-Scale/Micro Irrigation and Rainwater Harvesting for Food Security in Ethiopia. Addis Ababa International Water Management Institute, Working Paper 98.

AWULACHEW, S. B.; YILMA, A. D.; LOULSEGED, M.; LOISKANDL, W., AYANA, M.; ALAMIREW, T. 2007. Water Resources and Irrigation Development in Ethiopia. Colombo, Sri Lanka: International WaterManagement Institute. 78p. (Working Paper 123)

AWULACHEW,S.B. AND MERREY,J.D.2007. Assessment of Small Scale Irrigation and Water Harvesting in Ethiopian Agricultural Development. International Water Management Institute (IWMI), Addis Ababa, Ethiopia.

BoA, 2009/2010. Arsi Nagelle District Agriculture and Rural Development office; Bureau of Agriculture (BoA) Arsi Nagelle, Ethiopia. Unpublished report.
BARROW CHRIS 1993.Water Resources and Agricultural Development in the Tropics.John Wiley and Sons, Inc., New York, USA.

BRABBEN,T.;ANGOD,C.;SKUTSCH,J.;SMITH,L.,2 004.Irrigation can sustain rural livelihood: evidence from Bangladesh and Nepal. HR Wallingford Ltd. UK.

DE FRAITURE,C.; MOLDEN, D.; WICHELNS, D.2009. Investing in water for food, ecosystems, and livelihoods: An overview of the comprehensive assessment of water management in agriculture. International Water Management Institute PMB, CT 112, Cantonments, Accra, Ghana.

DESSALEGN RAHMATO,1999. Water Resource Development in Ethiopia. Forum for Social Studies, Addis Ababa, Ethiopia.

DOUGHERTY T.C., HALL A.W.1995. Environmental impact assessment of irrigation and drainage projects. FAO. Rome Italy.

EEPA , 1997. Environmental Policy of the Federal Democratic Republic of Ethiopia (April 2, 1997) Addis Ababa, Ethiopia.

EEPA , 2003. Ethiopian Environmental Protection Authority (EEPA) (November, 2003). Environmental Impact Assessment Procedural Guideline Series 1. Addis Ababa, Ethiopia.

EEPA , 2004.Ethiopian Environmental Protection Authority (EEPA), 2004.Environmental impact assessment guidelines on irrigation. Addis Ababa, Ethiopia.

FAO, 1997. Irrigation potential in Africa: A basin approach. Roam, Italy.

FAO, 2005.Global information and early warning system on food and agriculture.World food program.Special report. Italy, Rome

FNG 2002. Federal Negarit Gazeta (FNG) of the Federal Democratic Republic of Ethiopia ,2002.Proclamation No. 299/2002.Environmental Impact Assessment Proclamation. December3,2002, Addis Ababa, Ethiopia.

GEBREGZIABHER,

G.; NAMARA,E.R.;HOLDEN,S. Poverty reduction with irrigation investment: An empirical case study from Tigray, Ethiopia. Agricultural Water development, 2009, 96 (12), P. 1837-1843.

IFAD (International Fund for Agricultural Development) 2005. Special country program phase II. Interim evaluation report number 1643-ET, Ethiopia IFAD (International Fund for Agricultural Development).

MAKOMBE, G., KELEMEWORK, D., AREDO, D., A comparative analysis of rain-fed and irrigated agricultural production in Ethiopia. Irrigation and Drainage Systems 2007, 21, p. 35-44. http://dx.doi.org/10.1007/s10795-0079018-2

MoWR (Ministry of Water Resources) 2001. Irrigation development strategy (Component of the water sector development program). Draft report. Ethiopia, Addis Ababa.

PEDEN, D.; DUBALE, P.; TSEGAYE, E.; BEHAILU, M.; TADESSE, G.; GEBREMEDHIN,G.,2002. Community-based irrigation management in Ethiopia: Strategies to enhance human health, livestock and crop production, and natural resource management. International Water Institute Management Institute (IWMI), Addis Ababa, Ethiopia.

TESFAYE, A.; BOGALE, A.; NAMARA, E.R.; BACHA, D. The impact of small-scale irrigation on household food security: The case of Filtino and Godino irrigation schemes in Ethiopia. Irrigation and Drainage System, 2008, 22:p,145-158. 
Mr. Mihret Dananto Ulsido - MSc in Water Resources Engineering, MSc in Resources Engineering, Lecturer School of Biosystems and Environmental Engineering, Hawassa Institute of Technology, Hawassa University, Ethiopia.

Main research area: System analysis, Water resources engineering and management, contaminant transport, environmental quality, surface and ground water hydrology.

Address: P.O.Box 5, SNNPR State, Hawassa University, Hawassa Ethiopia

Tel.: $\quad+251911040234$

E-mail: mihret@gmail.com

Ermias Alemu Demisse - a PhD candidate at the Department of Water Resources \& Irrigation Engineering, Institute of Technology Arba Minch University, Ethiopia

Main research area: Integrated river basin management (water resources development, water resources management and irrigation), Irrigation System analysis (technical, social, environmental and economical issues), Water resources engineering and management.

Address: $\quad$ P.O. Box 21, SNNPR State, Arba Minch Institute of Technology, Arba Minch, Ethiopia

Tel.: +251911479239

E-mail: ermialem@gmail.com
PhD Mekonnen Ayana Gebul- Associate Professor, Director of Institute of Water Research at Arba Minch University, Department of Water Resources \& Irrigation Engineering, Institute of Technology Arba Minch University, Ethiopia.

Main research area: River basin governance (benefit sharing, cooperation, negotiations and managing interdependencies), River basin planning (integrating water, land use, agriculture and ecosystems in watersheds and river basins), integrated river basin management (water resources development, water resources management and irrigation)

Address: P.O. Box 21, SNNPR State, Arba Minch Institute of Technology, Arba Minch, Ethiopia

Tel.: $\quad+251916831052$

E-mail: meko_amu@yahoo.com

Mr. Adugna Eneyew Bekelle, MSc in Rural Development, lecturer department of Agricultural Economics and Extension, College of Agriculture \& Veterinary Medicine, Jimma University, Ethiopia

Main research area: Rural livelihoods, food security, poverty, sustainable use of Natural Resources

Tel.: $\quad+251911762519$

E-mail: adugna_e@yahoo.com 


\title{
Mažųjų drėkinimo sistemų poveikis aplinkai: Etiopijos riftų slėnio baseino pavyzdys
}

\author{
Mihret Dananto Ulsido ${ }^{1}$, Ermias Alemu Demisse ${ }^{2}$, Mekonen Ayana Gebul ${ }^{2}$, \\ Adugna Eneyew Bekelle ${ }^{3}$ \\ ${ }^{1}$ Biologiniu sistemu ir aplinkos inžinerijos mokykla, Hawasa universitetas, Etiopija \\ ${ }^{2}$ Vandens ištekliu ir drèkinimo sistemu inžinerijos fakultetas, Arba Minch universitetas, Etiopija \\ ${ }^{3}$ Žemes ükio ekonomikos ir plètros fakultetas, Jimma universitetas, Etiopija
}

(gauta 2013 m. vasario mèn., priimta spaudai 2013 m. kovo mèn.)

Straipsnyje pateiktas tyrimas, kuris buvo atliktas Riftų slènio ežerų baseine. Jis yra vienas iš dvylikos didžiausių upių baseinų Etiopijoje. Atliekant tyrimą, buvo siekiama îvertinti skirtingų drékinimo sistemų daromą poveikį aplinkai. Tyrimo rezultatai rodo, kad pagrindinès drékinimo sistemų keliamos problemos yra miškų nykimas, menkas vandens šaltinių tvarkymas, dirvos druskingumas, dirvos rūgštingumas, ligos ir vandens pritakos trikdžiai. Atliekant tyrimą ivertinta, kurios drèkinimo sistemos daro mažesni poveiki aplinkai. 